\title{
Green synthesis and characterization of silver nanoparticles using Indigofera aspalathoides leaf extract and study of its Antibacterial, Antioxidant, and Anti-cancerous activities
}

\author{
GANDHIRAJ V. ${ }^{1 *}$, SATHISH KUMAR K. ${ }^{2}$ \\ ${ }^{1}$ Department of Biotechnology, V.S.B. Engineering College, Karur, Tamil Nadu, 639 111, India \\ ${ }^{2}$ Department of Chemical Engineering, Sri Sivasubramaniya Nadar College of Engineering, \\ Kalavakkam, Tamil Nadu, 603110, India
}

\begin{abstract}
Indigofera aspalathoides is an indigenous medicinal plant with copious phytochemical and pharmacological benefits. The crude extract from the leaves of Indigofera apalathoides aids in the bioreduction of silver nitrate into silver ions which results in the formation of colloidal silver nanoparticles. Critical physio-chemical parameters such as temperature, $\mathrm{pH}$, substrate ratio (ratio of leaf extract and silver nitrate solution) and incubation time were optimized to increase the yield and efficiency of the nanoparticle formation. Synthesized nanoparticles were then characterized by performing a set of spectral analyses such as UV, FTIR, XRD, SEM, EDAX and AFM, later its bioactivity was also assessed.

Characteristic UV-Vis absorption peak $\left(\lambda_{\max }\right)$ at the range of $360-390 \mathrm{~nm}$ indicated silver nanoparticle formation and XRD pattern revealed the crystalline nature, while the average grain size was estimated to be $68.5 \mathrm{~nm}$ using Scherrer's formula. SEM image clearly depicted the square shaped silver nanoparticles, which were synthesized using Indigofera aspalathoides leaf extract. Confirmation of formation of silver nanoparticles were carried out using EDAX spectrum. IC 50 value of free radical scavenging occurred at a lower concentration of $300 \mu \mathrm{g} / \mathrm{ml}$, while a maximum inhibition zone of $13 \mathrm{~mm}$ was recorded against pathogenic bacterial strains and $6.7 \mathrm{~mm}$ was recorded against pathogenic fungal strains. Further, the silver nanoparticle cytotoxicity analysis was also carried out using MCF 7 cell line and IC 50 was found out to be $5.9 \mu \mathrm{g} / \mathrm{ml}$. Silver nanoparticles which are green synthesized using the aqueous extract of Indigofera aspalathoides proved as an effective broad-spectrum antibiotic as well as an efficient antioxidant and an anti-cancerous agent.
\end{abstract}

Keywords Indigofera aspalathoides, SEM, AFM, Silver nanoparticles, MCF.

To cite this article: GANDHIRAJ V, SATHISH KUMAR K. Green synthesis and characterization of silver nanoparticles using Indigofera aspalathoides leaf extract and study of its Antibacterial, Antioxidant, and Anti-cancerous activities. Rom Biotechnol Lett. 2021; 26(3): 2606-2617. DOI: 10.25083/rb1/26.3/2606-2617 


\section{Introduction}

With an advent inflation of interest towards nanotechnology and nano-science along with its vast range of applications in the field of drug delivery, bio-remediation, photonic devices, polymer fabrication; newer techniques have been adopted for the efficient, economical, eco-friendly and effective ways of synthesizing the nanoparticles (GILAKI [1]; GOODSELL [2]). Since the synthesized nanomaterials differ from its parent bulk compound in many physio-chemical aspects, there always arises a cautious evaluation in the design and development of these nanomaterials. There has been development of various methods in the past to synthesize different types of nanoparticles from various sources according to the nature of the nanoparticles to be synthesized (PUTHETI \& al [3]). However, silver nanoparticles which are green-synthesized are eco-friendly and also have very little toxicity level (WANG \& al [4]). Nowadays plant mediated biological synthesis of nanoparticle is gaining importance due to its simplicity and cost-effective approach (FAROOQUI \& al [5]). Generally, plants are good chelating agent and reducing agent due the presence of high antioxidant properties (KUMAR \& YADAV [6]). These extracts contain different types of organic reducing agents which include: phenols, alkaloids, flavonoids, tannins, terpenoids, saponins, steroids, glycosides and amino acids (MUKUNTHAN \& BALAJI [7]). The organic synthesis of nanoparticle requires alteration in both the physical and chemical properties of the bulk materials. The bio-active phytoconstituents of the plants acts as good reducing and capping agent which tends to reduce the size and also limit the nucleation of growth of the substrate to nano and micro molecular size (THAKKAR \& al [8]).

The depth of knowledge in nano-materials has led to various discoveries in the field of nano-medicine, nanobiotechnology and in that aspect nano-toxicology research is also gaining great importance, which leads to discovering its use as an effective bactericidal agent (KIM \& al [9]). Among the various organic and inorganic nanoparticles, silver (Ag) metal-based nanoparticles have been receiving an increased interest (SONG \& al [10]). Reduced toxicity and increased microbicidal activity are found in silver (JAIN \& al [11]). Nanoparticles of silver has exceptional physical and chemical properties along with very low preparation cost and considered as an impressive structure to be analyzed (MARAMBIO-JONES \& HOEK [12]). Silver nanoparticles are utilized in various fields including diagnostics, therapeutics, food preservation and bio sensors.

Indigofera belongs to the family of Leguminosae (Fabaceae), commonly known as 'Shivanarvembu' in Tamil. They are mostly shrubs, but some are herbaceous, small trees of 6 feet height. According to the literature of traditional medicinal system (Ayurveda), various parts of the plant Indigofera aspalathoides was used as a good cooling agent and as a demulcent (RAMANA [13]). The chemical components include: steroids, tri-terpenoids, alkaloids, phenolic groups, flavones, saponins, tannins, sugars and amino acids (TAMILSELVI \& al [14]), which has a potential in the bio-reduction of silver nitrate to silver nanoparticles. The plant material is used as a treatment for several diseases caused by pathogenic microbes (SILVER $\&$ al [15]).

\section{Materials and Methods}

\section{Reagents and chemicals}

Fresh leaves of Indigofera aspalathoides were collected from the hills of kollimalai, Tamil Nadu, India. The reagents used in the study were of analytical grade purchased from Sigma-Aldrich namely: silver nitrate, DPPH (1, 1-diphenyl-2-picrylhydrazyl), sodium nitro prusside, sulphonilamide, 1-naphthylethylenediamine and ammonium molybdate. The reagents and buffers were prepared freshly using Milli Q water.

\section{Preparation of plant extract}

The collected leaves were then washed using distilled water for several time to remove dust and allowed to shade dry. Completely dried leaves were blended into fine powder using a homogenizer. $5 \mathrm{~g}$ of Indigofera aspalathoides dry leaf powder was dissolved in $100 \mathrm{ml}$ of Milli Q water and made into a homogenized solution by continuously stirring at $60^{\circ} \mathrm{C}$ for 1 hour using a magnetic stirrer. The extract was then filtered using Whatman filter paper (No. 1) and the resulting filtrate was then stored at $4^{\circ} \mathrm{C}$ until further use (KHANDELWAL SINGH \& al [16]).

\section{Qualitative phytochemical analysis}

The aqueous extract of Indigofera aspalathoides was subjected to phytochemical analysis for the detection of several bioactive phyto-components (GARIMA \& al [17]).

\subsection{Test for flavonoids}

$2 \mathrm{ml}$ of aqueous extract was taken and mixed with few drops of $20 \%$ sodium hydroxide. Formation of intense yellow color was observed, which will disappear upon addition of $70 \%$ diluted HCL. The formation and disappearance of yellow color indicates the presence of flavonoids.

\subsection{Test for alkaloids}

$10 \mathrm{ml}$ of extract was taken and $8 \mathrm{ml}$ picric acid was added to it. The formation of orange color was observed, indicating the presence of alkaloids.

\subsection{Test for saponins}

To the aqueous extract of $2 \mathrm{ml}, 5 \mathrm{ml}$ of water was added and vigorously shaken. The formation of bubbles and persistent foam indicates the presence of saponins.

\subsection{Test for tannins}

$10 \%$ of alcoholic ferric chloride was added to $2 \mathrm{ml}$ of extract, formation of blackish blue color was observed. The change to blue black color indicates the presence of tannins.

\subsection{Test for phenolic compounds}

$2 \mathrm{ml}$ of extract was taken and $2 \mathrm{ml}$ of $5 \%$ ferric chloride was added to it. The formation of blue color was observed indicating the presence of phenolic compounds.

\subsection{Test for terpenoids}

From the aqueous extract, $1 \mathrm{ml}$ was added to a test tube. To the tube $0.5 \mathrm{ml}$ of chloroform followed by a few drops of concentrated $\mathrm{H}_{2} \mathrm{SO}_{4}$ was added. The formation of reddish-brown color was observed, indicating the presence of terpenoids. 


\subsection{Test for glycosides}

$1 \mathrm{ml}$ of aqueous extract was taken. To that tube $0.5 \mathrm{ml}$ of glacial acetic acid and $1 \%$ aqueous ferric chloride was added. The formation of brownish ring was observed indicating the presence of glycosides.

\subsection{Tests for sugars}

\subsubsection{Fehling's Test}

A fraction of the extract was treated with Fehling's solution then heated in a boiling water bath and observed for the formation of a brick red precipitate.

\subsubsection{Benedict's Test}

The leaf extract was added with Benedict's solution and subjected to heating in a boiling water bath. Formation of red precipitate shows the presence of sugars.

\section{Bioreduction of silver nanoparticles}

$10 \mathrm{ml}$ of the leaf extract of Indigofera aspalathoides was mixed with aqueous AgNO3 solution of $90 \mathrm{ml}$ (1:9 ratio of plant extract and silver nitrate solution) and continuously agitated using magnetic stirrer for $60 \mathrm{~min}$ at $30^{\circ} \mathrm{C}$. Reduction of silver nitrate takes place rapidly as indicated by a color change to dark brown from pale yellow. Then the mixture was subjected to overnight incubation and then centrifuged at $10,000 \mathrm{rpm}$ for $10 \mathrm{~min}$ to precipitate the formed silver nanoparticles. The precipitate was washed with absolute ethanol and dried at room temperature (SHANKAR $\&$ al [18]). Finally, a powder containing silver nanoparticles was acquired and stored at $4^{\circ} \mathrm{C}$ until further use.

\section{Fixation of different parameters}

The critical parameters such as the molarity of silver nitrate solution $(1 \mathrm{mM}, 2 \mathrm{mM}, 3 \mathrm{mM}, 4 \mathrm{mM}$ and $5 \mathrm{mM})$, temperature $\left(30^{\circ} \mathrm{C}, 60^{\circ} \mathrm{C}, 90^{\circ} \mathrm{C}\right.$ and $\left.120^{\circ} \mathrm{C}\right), \mathrm{pH}(4,5,7$ and 8$)$, incubation time $(6,12,18,24 \mathrm{hrs})$ and ratio of plant extract with silver nitrate solution $(1: 1,1: 1.5$ and $1: 2)$ were varied and the optimal conditions for effective synthesis of silver nanoparticles with higher yield and increased stability were identified.

\section{Characterization of biosynthesized silver nano- particles}

The characterization of the synthesized silver nanoparticles was done using various spectral analysis.
UV-Visible spectroscopy analysis was carried out on a Systronic UV-Visible Spectrophotometer 117 with a resolution of $\pm 1 \mathrm{~nm}$ between $200-800 \mathrm{~nm}$ processing a scanning speed of $200 \mathrm{~nm} / \mathrm{min}$. Jasco Fourier Transform Infrared Spectrometer was used for FTIR spectroscopic analyses. Fourier transforms infrared spectra generated by the absorption of electromagnetic radiation in the frequency range 400 to $4000 \mathrm{~cm}^{-1}$. Silver nanoparticle characterization was also carried out using XRD diffraction method using Rigaku Ultima III Max (Japan). XRD was used to determine the nanoparticles and their size were calculated using Scherrer's formula. SEM and EDAX were carried out with Field Emission Scanning Electron microscopy (FESEM) with EDS Carl Zeiss, Sigma. Sample was prepared on a carbon coated copper grid by just dropping a very small amount of the sample on the grid, excess solution was removed using a blotting paper and then the film on the SEM grid were allowed to dry for analysis. Elemental analysis (EDAX) was done to detect the presence of the silver signals in the nanoparticles to ensure that the formed nanoparticles are composed of silver metal at its core. A thin film of the sample was prepared on a glass slide by dropping $100 \mu 1$ of the sample on the slide and allowed to dry for $5 \mathrm{~min}$. The slides were then scanned with the Atomic Force Microscopy. The AFM characterization was carried out at ambient temperature in non-contact mode using silicon tips with varying resonance frequencies at a linear scanning rate of $0.5 \mathrm{~Hz}$ with an Agilent AFM 5500 model (VEERASAMY \& al [19]).

\section{Antioxidant Assay}

\subsection{DPPH}

The ability of the nanoparticles to bleach DPPH was quantified using the antioxidant scavenging assay (PREMA [20]). Methanol was used to dissolve synthesized silver nanoparticles. To $20 \mu 1$ of the synthesized nanoparticles, $0.5 \mathrm{ml}$ of DPPH solution and $480 \mu \mathrm{l}$ of methanol were added and were incubated in dark for 30 minutes at room temperature. Using methanol as blank, the absorbance of the samples were measured at $518 \mathrm{~nm}$ with the help of an ELISA plate reader (Model no. 680). Finally, the percentage of free radical scavenging activity of the synthesized silver nanoparticles was determined as follows:

$$
\text { Scavenging activity }(\%)=\frac{A b s_{\text {Control }}-A b s_{\text {Sample }}}{A b s_{\text {Control }}} * 100
$$

\subsection{Nitric oxide scavenging activity}

$100 \mu \mathrm{l}$ of varying concentrations $(100-500 \mu \mathrm{g} / \mathrm{ml})$ of samples were taken. $1 \mathrm{ml}$ of $5 \mathrm{mM}$ sodium nitroprusside prepared in $0.025 \mathrm{M}$ of phosphate buffer saline ( $\mathrm{pH} 7.4)$ was added to the samples and subjected to incubation for 3 hours at $30^{\circ} \mathrm{C}$ (RAO \& SAVITHRAMMA [21]). Then, using $1 \mathrm{ml}$ of Griess reagent containing $1 \%$ sulphonilamide,

$$
\text { Scavenging activity }(\%)=\frac{A b s_{\text {Control }}-A b s_{\text {Sample }}}{A b s_{\text {Control }}} * 100
$$

\subsection{Total antioxidant Assay}

$100 \mu \mathrm{l}$ of varying concentrations $(100-500 \mu \mathrm{g} / \mathrm{ml})$ of the samples were taken and combined with $1 \mathrm{~mL}$ of reagent solution $(0.6 \mathrm{M}$ sulfuric acid, $28 \mathrm{mM}$ sodium phosphate and $4 \mathrm{mM}$ ammonium molybdate). The tubes
$0.1 \% \mathrm{~N}$ 1-naphthylethylenediamine, $2 \%$ orthophosphoric acid prepared in phosphate buffer ( $\mathrm{pH}-7.4)$, the samples were diluted. The absorbance was measured at $550 \mathrm{~nm}$ on a Bio-Rad ELISA plate reader model no. 680 spectrophotometer. The same procedure was followed in standard ascorbic acid and the results were compared with the test sample.

were then incubated for $90 \mathrm{~min}$ at $95^{\circ} \mathrm{C}$. Using UV-VIS spectro-photometer, the absorbance of the samples was measured at $695 \mathrm{~nm}$. The results were compared against the standard ascorbic acid (ARUNACHALAM $\&$ al [22]). 


\section{Antimicrobial activity \\ 8.1. Microorganisms}

The pure bacterial strains such as Bacillus subtilis (MTCC 121), E. coli (MTCC 1302), Staphylococcus aureus (MTCC 1144), Pseudomonas aeruginosa (MTCC 1688) and Klebsiella pneumoniae (MTCC 4030) and pathogenic fungus such as Aspergillus niger (MTCC 281), Aspergillus flavus (MTCC 277), Aspergillus fumigatus (MTCC 121), Mucor sp. (MTCC 3340) and Trichoderma sp. (MTCC 3197), were obtained from King Institute of Preventive Medicine, Guindy, Tamil Nadu, India. The cultures were maintained at $4{ }^{\circ} \mathrm{C}$ until processing.

\subsection{Preparation of inoculum}

A loop full of active cultures from the stock were inoculated into the test tubes of broth for bacteria (nutrient broth) and fungi (potato dextrose broth) and incubated at $37^{\circ} \mathrm{C}$ for 24 hours (bacteria) and room temperature for 42 hours (fungi). The agar disk diffusion method was employed for the assay.

\subsection{Antibacterial activity}

Both the aqueous leaf extract of Indigofera aspalathoides and the nanoparticles synthesized from the same were subjected to antibacterial activity by disk diffusion on Mueller Hinton Agar (MHA) medium. The inoculum was spread on to the solidified medium using sterile swab. $20 \mu \mathrm{l}$ of sample at different concentrations $1000 \mu \mathrm{g}, 500 \mu \mathrm{g}, 250 \mu \mathrm{g}$, $125 \mu \mathrm{g} \& 62.5 \mu \mathrm{g} ; 20 \mu \mathrm{l}$ of DMSO as negative control and $10 \mu \mathrm{l}$ containing $10 \mu \mathrm{g}$ of streptomycin as positive control were loaded on to the respective disc in the MHA plates. These plates were then incubated at $37^{\circ} \mathrm{C}$ for 24 hours. The diameter of the zone of inhibition was then measured to evaluate the antibacterial activity (OVAIS \& al [23]).

\subsection{Antifungal activity}

Antifungal activity of sample was determined by disc diffusion method on Potato Dextrose Agar (PDA) medium (RATHEESH \& al [24]). The fungal spores were spread on the solid plates with sterile swab moistened with the fungal suspension. $20 \mu \mathrm{l}$ of sample (concentration: $1000 \mu \mathrm{g}, 500 \mu \mathrm{g}, 250 \mu \mathrm{g}, 125 \mu \mathrm{g} \& 62.5 \mu \mathrm{g}), 20 \mu \mathrm{l}$ of DMSO as negative control and $10 \mu \mathrm{l}$ containing $10 \mu \mathrm{g}$ of ketoconazole as positive control were loaded onto the respective disc in the PDA plates. These plates were incubated for 42 hours at room temperature. Then the activity was determined by measuring the diameter of zone of inhibition.

\section{GC-MS analysis}

The qualitative and quantitative data of compounds present in Indigofera aspalathoides leaf extract was determined using GC-MS analysis (SONG \& KIM [25]).
10. Anticancer activity of the aqueous leaf extract from indigofera aspalathoides and its synthesized silver nanoparticles

\subsection{Cancer cell line}

Breast cancer cell line (MCF-7) was obtained from National Centre for Cell Sciences, Pune (NCCS). The cells were maintained in Minimal Essential Media supplemented with $10 \%$ FBS, penicillin $20 \mu \mathrm{l}(100 \mathrm{U})$, and streptomycin $(1000 \mu \mathrm{g} / \mathrm{ml})$ and amphotericin B $(100 \mu \mathrm{g} / \mathrm{ml})$ in a humidified atmosphere of $5 \% \mathrm{CO}_{2}$ at $37{ }^{\circ} \mathrm{C}$ (KRISHNARAJ \& al [26]).

\subsection{In vitro cytotoxicity activity (MTT Assay)}

The cytotoxicity activity of synthesized silver nanoparticles as well as leaf extract of Indigofera aspalathoides were determined on MCF7 cell line by the MTT assay method (SHANKAR \& al [27]). The cells were plated in $0.2 \mathrm{ml}$ of medium in 96 well plates and incubated at $5 \% \mathrm{CO}_{2}$ for 72 hours. Various concentrations of the samples were dissolved in $0.1 \%$ DMSO and added into the corresponding cells containing the medium. The set up was incubated at $5 \% \mathrm{CO}_{2}$ for 48 hours. After incubation, the sample solution was removed and washed using phosphatebuffered saline ( $\mathrm{pH}$ 7.4). Then add $20 \mu \mathrm{l} /$ well of 3-(4, 5-dimethyl-2-thiazolyl)-2, 5-diphenyl--tetrazolium bromide (MTT) in phosphate- buffered saline solution and then incubated for 4 hours. To the mixture, $1 \mathrm{ml}$ of DMSO was added (PRASHAR \& al [28]). Determination of viable cells were carried out by estimating its absorbance at $540 \mathrm{~nm}$ using a spectrophotometer. The effect of the samples on MCF7 cell lines was expressed as the percentage of cell viability; this was calculated using the following formula:

$$
\% \text { cell viability }=\frac{\text { sample absorbance }}{\text { control absorbance }} * 100
$$

\section{Results \& Discussion}

\section{Qualitative phytochemical analysis}

Aqueous leaf extract of Indigofera aspalathoides was subjected to the phytochemical analysis and the results are expressed in Table 1. Presence of the various bioactive phytochemical groups such as alkaloids, flavonoids, phenolic compounds, saponins and tannins are detected and confirmed. Thus, it is evident that the bio-reduction of silver nitrate into silver nanoparticles were efficiently carried out by the presence of aforementioned bioactive phyto-components in the crude extract (CHANDRAN \& al [29]).

Table 1. Phytochemical analysis of aqueous extract of $I$. aspalathoides leaves

\begin{tabular}{|c|c|c|}
\hline S. No & Phytochemical & $\begin{array}{c}\text { Aqueous extract of Indigofera } \\
\text { aspalathoides }\end{array}$ \\
\hline 1. & Tannins & - \\
\hline 2. & Saponins & + \\
\hline 3. & Flavonoids & + \\
\hline 4. & Alkaloids & + \\
\hline 5. & Phenols & + \\
\hline 6. & Sugars & + \\
\hline 7. & Terpenoids & - \\
\hline 8. & Glycosides &
\end{tabular}




\section{Optimization of the formulation condition of silver nanoparticles}

Upon mixing the fresh crude extract of Indigofera aspalathoides with silver nitrate $\left(\mathrm{AgNO}_{3}\right)$ solution, the native color of the extract was completely transformed within a period of 10 minutes, indicating silver ion reduction into silver nanoparticles.

The efficiency of the synthesized silver nanoparticles using Indigofera aspalathoides leaf extract were optimized by varying the critical response parameters and the results are shown in Figure 1. UV-Visible Spectrum was used as a provision to differentiate the efficiency between the varying parameters and the condition which demonstrates maximal intensity of the characteristic UV-visible spectral peaks of silver nanoparticles. These spectral peaks were considered as the optimal conditions for nanoparticle synthesis. From Figure 1A it is understood that the optimal concentration for silver nanoparticle synthesis is $5 \mathrm{mM}$ (DWIVEDI \& GOPAL [30]). Initially, there is a reduction in the size due to reduction in aggregation of nanoparticles. Figure 1B suggests that increasing temperature increases nanoparticle formation rate unless the temperature reaches $80^{\circ} \mathrm{C}$ after which the rate of nanoparticle formation decreases, indicating the optimal temperature for silver nanoparticle synthesis to be $80^{\circ} \mathrm{C}$. Figure $1 \mathrm{C}$ shows suppression of nanoparticle formation at alkali conditions whereas acidic conditions enhance silver nanoparticle formation. Agglomerative bulk particles were formed at higher $\mathrm{pH}(\mathrm{pH} 9)$; whereas reduced size and highly dispersed nanoparticles were formed at lower $\mathrm{pH}(\mathrm{pH} 5)$. At neutral $\mathrm{pH}$, only meager volume of the nanoparticles was formed, which can be indicated from the Figure 1C.
A

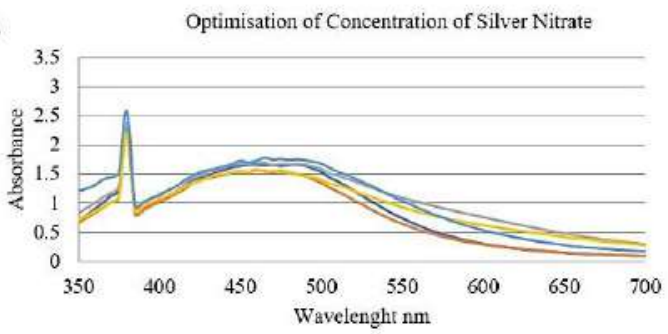

C

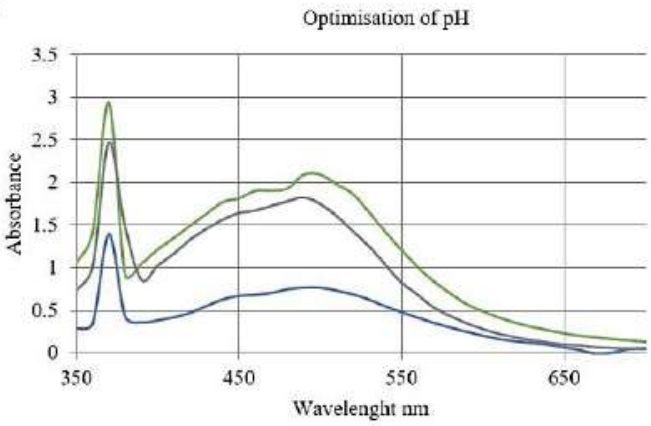

$E$

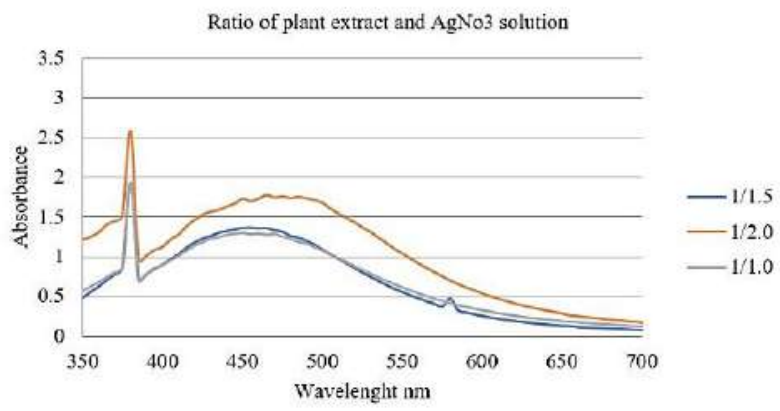

B

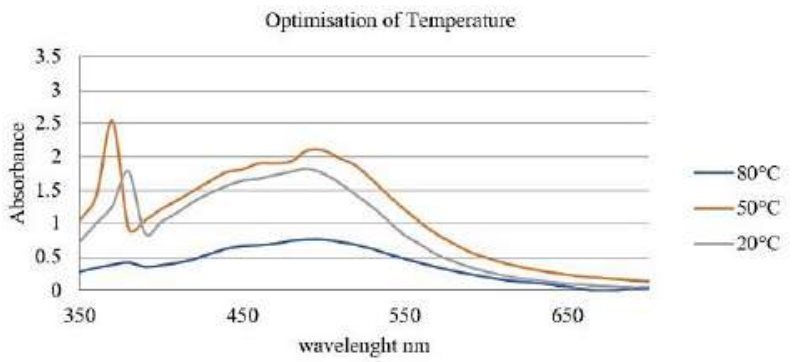

D
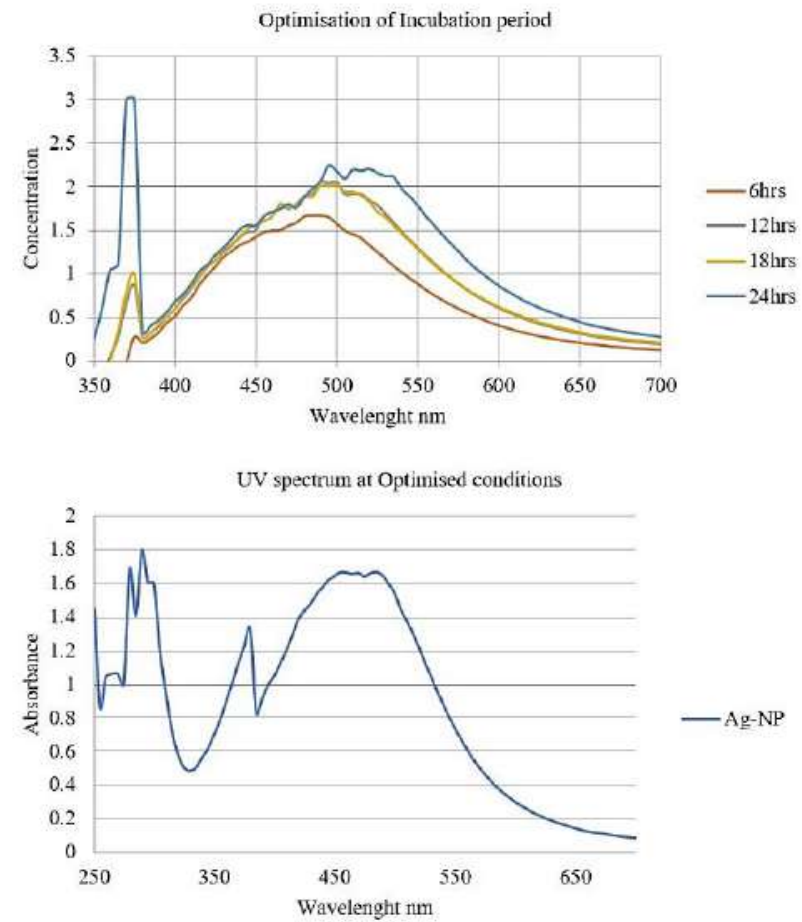

Figure 1. Optimisation protocol. 1A: Optimization of Concentration of $\mathrm{AgNO}_{3}$. 1B: Optimization of Different Temperature. 1C: Optimization of Different pH. 1D: Optimization of Incubation period. 1E: ratio of plant extract and $\mathrm{AgNo}_{3}$ solution. 1F: UV-VIS Absorption spectrum of silver nanoparticles synthesized by optimal conditions.

Figure 1D shows that, prolonged incubation period yields increased quantity of silver nanoparticles. However, an optimum incubation period has to be determined to avoid agglomeration of silver nanoparticles to form large sized nanoparticles due to their instability over prolonged period of time. The optimum time required for the complete reaction for silver nanoparticle formation was found to be 24 hours under constant agitation. Ratio of silver 
nitrate solution $(5 \mathrm{mM})$ and the leaf extract was altered to investigate the optimum composition to maximize the silver nanoparticle yield. Figure 1E, suggests that the optimum silver nitrate to crude extract ratio to be 1:2 based on the number of trials and the optimum yield (SATHYAVATHI \& al [31]).

The comprehensive optimal conditions for the reaction were: temperature $-50^{\circ} \mathrm{C}$, incubation period -24 hours, concentration of silver nitrate $-5 \mathrm{mM}$, pH- slightly acidic and the ratio of Indigofera aspalathoides leaf extract and silver nitrate solution was 1:2 (SINGHAL \& al [32]). Maximum absorbance peak was observed at $490 \mathrm{~nm}$ and a shoulder was seen at $380 \mathrm{~nm}$ confirming the silver nanoparticle formation as illustrated in the Figure $1 \mathrm{~F}$.

\section{Characterization of biosynthesized silver nano- particles}

The spectral characterization of silver nanoparticles using FTIR is shown in Figure 2A. The interaction of nanoparticles with the phytochemicals of Indigofera

A

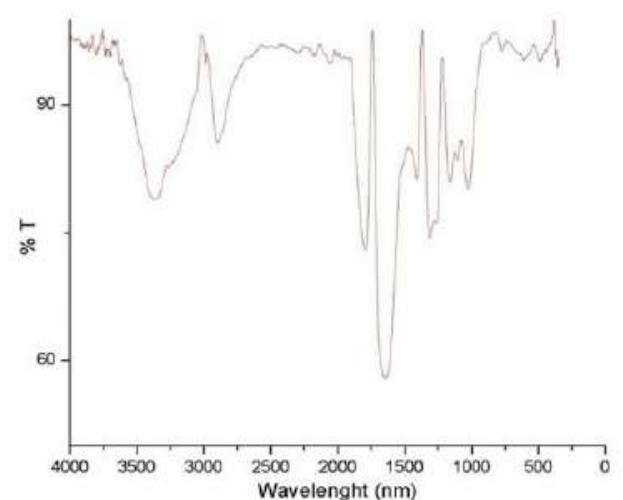

C

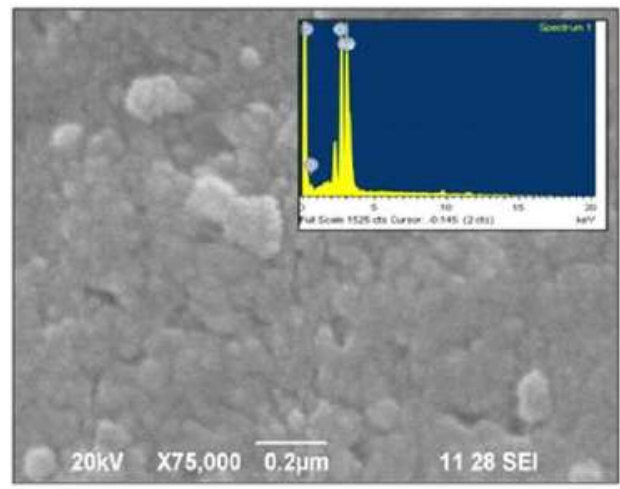

aspalathoides showing intense peaks at $3350 \mathrm{~cm}^{-1}$ corresponding to $\mathrm{N}-\mathrm{H}$ stretch $\left(1^{\circ}, 2^{\circ}\right.$ amines, amides), $2726.66 \mathrm{~cm}^{-1}$ corresponding to $=\mathrm{C}-\mathrm{H}$ stretch (alkenes), $1724.42 \mathrm{~cm}^{-1}$ corresponding to $\mathrm{C}=\mathrm{O}$ stretch (esters, saturated aliphatic), $1635.69 \mathrm{~cm}^{-1}$ corresponding to $\mathrm{N}-\mathrm{H}$ bend ( $1^{\circ}$ amines), $1446.66 \mathrm{~cm}^{-1}$ corresponding to $\mathrm{C}-\mathrm{H}$ bend (alkanes), $1373.36 \mathrm{~cm}^{-1}$ corresponding to $\mathrm{C}-\mathrm{H}$ rock (alkanes), $1284.63 \mathrm{~cm}^{-1}$ corresponding to $\mathrm{C}-\mathrm{H}$ wag (-CH2X) (alkyl halides), $1122.61 \mathrm{~cm}^{-1}$ corresponding to $\mathrm{C}-\mathrm{N}$ stretch (aliphatic amines), $1070.53 \mathrm{~cm}^{-1}$ corresponding to $\mathrm{C}-\mathrm{N}$ stretch (aliphatic amines), $856.24 \mathrm{~cm}^{-1}$ corresponding to $\mathrm{O}-\mathrm{H}$ bend carboxylic acids, $744.56 \mathrm{~cm}^{-1}$ corresponding to $\mathrm{N}-\mathrm{H}\left(1^{\circ}, 2^{\circ}\right.$ amines $), 698.25 \mathrm{~cm}^{-1}$ corresponding to $\mathrm{C}-\mathrm{H}$ "loop" stretch(aromatics), relative shift in position and intensity distribution were confirmed with FTIR. These include single bond stretches and a wide variety of bending vibrations. The FTIR analysis revealed the significance of phytochemical compounds in the process of bio-reduction of silver nitrate into silver nanoparticles (SINGH \& al [33]).

B

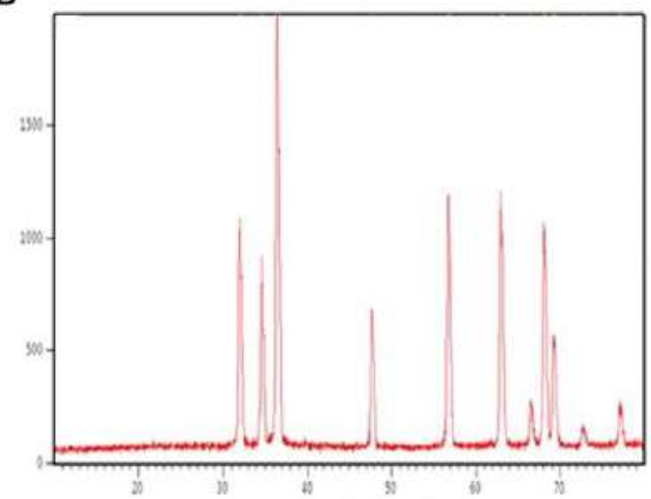

D

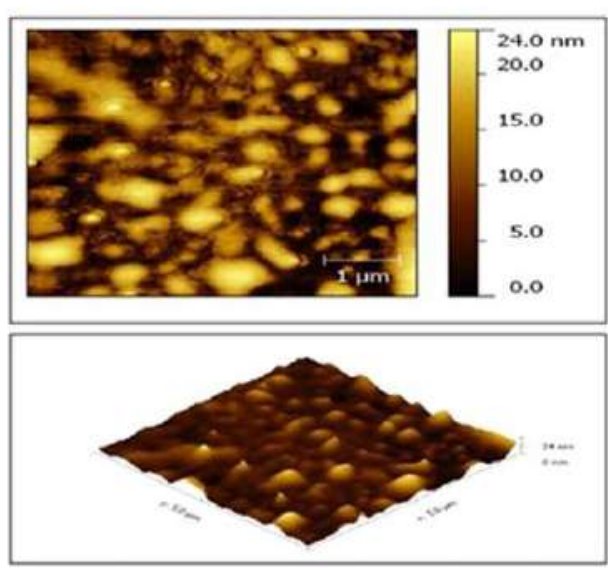

Figure 2. Nanoparticle characterization. 2A: FT-IR Spectrum of synthesized silver nanoparticles. 2B: X-ray diffraction pattern of silver nanoparticles. 2C: SEM and EDAX analysis of silver nanoparticles. 2D: AFM images of silver nanoparticles.

Silver nanoparticles synthesized using the leaf extract by green chemistry technique was further confirmed by observing the characteristic peaks in the $\mathrm{X}$ - ray structural diffraction pattern as shown in Figure 2B, which resembles to that of the crystal nature of nanoparticles. The average grain size of nanoparticles was determined using Scherrer's formula, $\mathrm{d}=(0.9 \lambda \times 1800) / \beta \cos \theta \pi$ and estimated as $68.5 \mathrm{~nm}$ (NEUN \& DOBROVOLSKAIA [34]). 
The inspection of SEM image clearly suggests that the purpose of phyto constituents is capping of silver ions which is revealed by observing the nanoparticle surface showing a faint thin layer. A square shape was roughly depicted by SEM for the silver nanoparticles. After an incubation period of $24 \mathrm{hrs}$, size of silver nanoparticle range was found out to be $40-70 \mathrm{~nm}$ and the representative SEM images are shown in Figure 2C. The analysis of biosynthesized nanoparticles through energy dispersive X-ray spectrophotometers confirmed the signal for the presence of elemental silver as illustrated in Figure 2C.

AFM was used to investigate the morphology of the silver nanoparticles. For this, glass slides were suspended in the solution for a certain period of time ( 24 hours). After the film formation, the slides were taken out and dried in air before being examined under AFM. Figure 2D shows that the particles were around $70 \mathrm{~nm}$ in size having spherical shape (CHOI \& al [35]). As the glass plates or slides are prepared by the above method, the results revealed time-dependent optical properties of the packing density of silver particles. The GCMS of the aqueous extract of $I$. aspalathoides was done and the results are tabulated in the Table 2. Mass spectral data revealed the presence of different phyto-constituents with significant bioactivity in the crude extract implying the evidence for the bio-reductive nature of the plant extract. High presence of compounds such as butanediol favors the process of bio-reduction.

Table 2. GC-MS analysis of aqueous crude Leaf extract of Indigofera aspalathoides

\begin{tabular}{|c|c|c|c|c|c|}
\hline Peak & Compound Name & R.T & Area $\%$ & $\begin{array}{l}\text { Molecular } \\
\text { Formula }\end{array}$ & $\begin{array}{l}\text { Molecular } \\
\text { Weight } \mathrm{g} / \mathrm{mol}\end{array}$ \\
\hline 1 & $\begin{array}{l}\text { Tris(cyclopentadienyl-cobalt)- } \\
\text { hexapropenylbenzene }\end{array}$ & 2.525 & 1.966 & $\mathrm{C}_{39} \mathrm{H}_{45} \mathrm{CO}_{3}$ & 690.1517 \\
\hline 2 & 2,3-Butanediol, [S-(R*.R*)]- & 2.882 & 7.288 & $\mathrm{C}_{4} \mathrm{H}_{10} \mathrm{O}_{2}$ & 90.0680 \\
\hline 3 & 2,3-Butanediol, [S-(R*.R*)]- & 3.119 & 18.911 & $\mathrm{C}_{4} \mathrm{H}_{10} \mathrm{O}_{2}$ & 90.0680 \\
\hline 4 & Tetraacetyl-d-xylonicnitrile & 3.216 & 13.248 & $\mathrm{C}_{14} \mathrm{H}_{17} \mathrm{NO}_{9}$ & 343.0903 \\
\hline 5 & 2,3-Butanediol, [S-(R*.R*)]- & 3.275 & 18.439 & $\mathrm{C}_{4} \mathrm{H}_{10} \mathrm{O}_{2}$ & 90.0680 \\
\hline 6 & Silanediol, dimethyl & 3.424 & 1.322 & $\mathrm{C}_{2} \mathrm{H}_{8} \mathrm{O}_{2} \mathrm{Si}$ & 92.0293 \\
\hline 7 & 1,2-Cyclopentanedione & 3.491 & 9.342 & $\mathrm{C}_{5} \mathrm{H}_{6} \mathrm{O}_{2}$ & 98.0367 \\
\hline 8 & 2,3-Butanediol, [S-(R*.R*)]- & 3.758 & 4.843 & $\mathrm{C}_{4} \mathrm{H}_{10} \mathrm{O}_{2}$ & 90.0680 \\
\hline 9 & Muramicacid & 3.892 & 1.462 & $\mathrm{C}_{9} \mathrm{H}_{17} \mathrm{NO}_{7}$ & 251.100 \\
\hline 10 & 2-Cyclopenten-1-one,2-hydroxy & 4.724 & 0.690 & $\mathrm{C}_{5} \mathrm{H}_{6} \mathrm{O}_{2}$ & 98.0367 \\
\hline 11 & $\begin{array}{l}\text { 16-Nitrobicyclo[1..4.0]hexdecan-1-o1- } \\
\text { 13-one }\end{array}$ & 4.821 & 3.687 & $\mathrm{C}_{16} \mathrm{H}_{27} \mathrm{NO}_{4}$ & 297.1940 \\
\hline 12 & Benzeneethanol, $\alpha \beta$-dimethyl- & 5.237 & 1.326 & $\mathrm{C}_{10} \mathrm{H}_{14} \mathrm{O}$ & 150.1044 \\
\hline 13 & Phenol,2,4-bis(1,1-dimethyllethyl) & 22.649 & 11.449 & $\mathrm{C}_{14} \mathrm{H}_{22} \mathrm{O}$ & 206.1670 \\
\hline 14 & $\begin{array}{l}\text { 2,5,5,8a-Tetramethyl-3-oxo- } \\
\text { 3,4,4a,5.6,7,8,8a-octahydronaphthalene- } \\
\text { 1-carboxylic acid,methyl esther }\end{array}$ & 28.199 & 1.515 & $\mathrm{C}_{16} \mathrm{H}_{24} \mathrm{O}_{3}$ & 264.1725 \\
\hline 15 & $\begin{array}{l}\text { 7,9-Di-tert-butyl-1-oxaspiro }(4,5) \text { deca- } \\
6,9 \text {-diene-2,8-dione }\end{array}$ & 31.549 & 1.151 & $\mathrm{C}_{17} \mathrm{H}_{24} \mathrm{O}_{3}$ & 276.1725 \\
\hline 16 & Hexanoic acid,2-ethyl-anhydride & 34.431 & 3.361 & $\mathrm{C}_{16} \mathrm{H}_{30} \mathrm{O}_{3}$ & 270.2194 \\
\hline
\end{tabular}

\section{Antioxidant activity}

The Indigofera aspalathoides extract and the synthesized silver nanoparticles were estimated for their free radical scavenging activity by comparing its inhibition percentage using various anti-oxidant assays like DPPH scavenging activity (Figure $3 \mathrm{~A} \&$ Table $3 \mathrm{~A}$ ), Nitric oxide scavenging activity (Figure $3 \mathrm{~B} \&$ Table $3 \mathrm{~B}$ ) and Total antioxidant assay with ascorbic acid as the standard (Figure 3C \& Table 3C). The comparative analysis of antioxidant activity of the silver nanoparticles along with the crude plant extract and also with standard ascorbic acid, the plant extract showed a percentage inhibition of $78 \%$ for DPPH assay, $42 \%$ for Nitric oxide assay and $46 \%$ for Total antioxidant assay. But enhanced antioxidant activity was seen in the silver nanoparticles showing a percentage inhibition of $85 \%$ for DPPH assay, $69 \%$ for Nitric oxide assay and $74 \%$ Total antioxidant assay. With reference to the inhibitory percentage of standard ascorbic acid; it was evident that the bio synthesized silver nanoparticles possess a greater extend of antioxidant activity. 
A

Aqueous extract of I. aspalathoides

= Silver nanoparticle synthesized from aqueous extract of $\mathrm{I}$. aspalathoides

ascorbic acid (Standard)

100

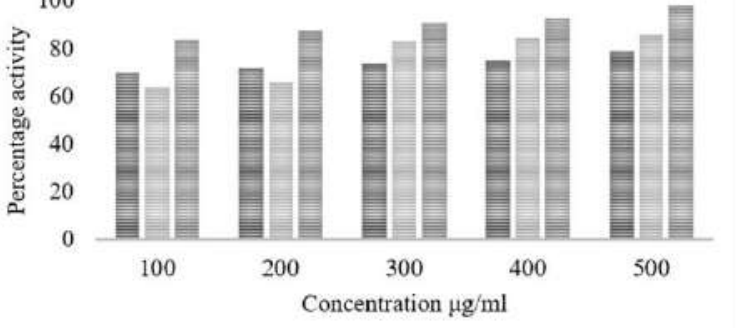

B

Nitric acid Assay

= Aqueous extract of $\mathrm{I}$. aspalathoides

= Silver nanoparticle synthesized from aqueous extract of I. aspalathoides

= Ascorbic acid (Standard)

100

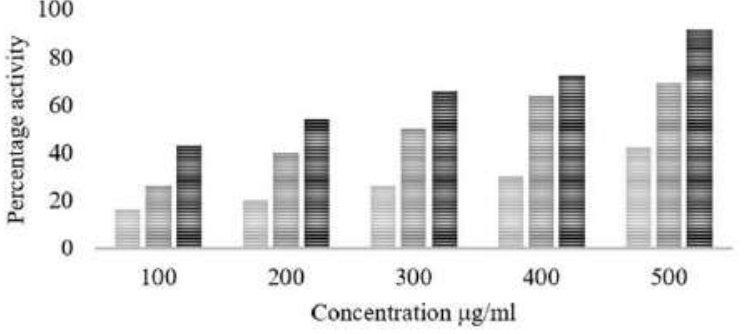

C

Total Anti-oxidant Assay

" Aqueous extract of $\mathrm{I}$. aspalathoides

$\equiv$ Silver nanoparticle synthesized from aqueous extract of $\mathbf{I}$. 100 aspalathoides

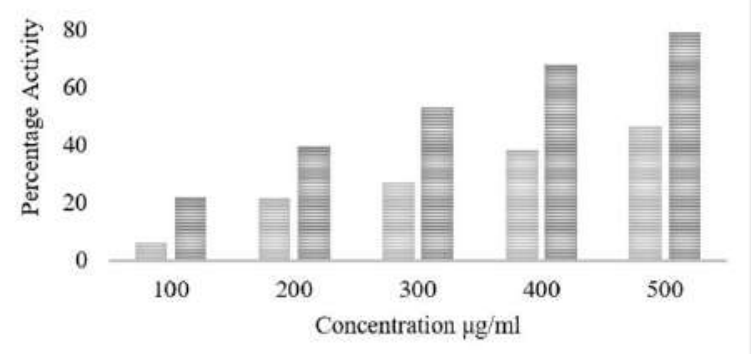

Figure 3. Antioxidant activity. 3A: DPPH Scavenging activity of synthesized silver nanoparticles. 3B: Nitric Oxide Scavenging activity of synthesized silver nanoparticles. 3C: Total Antioxidant activity of synthesized silver nanoparticles.

Table 3A. Antioxidant activity of Silver Nanoparticles against DPPH

\begin{tabular}{|c|c|c|c|c|}
\hline \multirow{2}{*}{ S. No } & Concentration $\mu \mathrm{g} / \mathrm{ml}$ & \multicolumn{3}{|c|}{ Percentage of Scavenging Activity } \\
\cline { 3 - 5 } & & $\begin{array}{c}\text { Aqueous extract of } \\
\text { I. aspalathoides }\end{array}$ & $\begin{array}{c}\text { Silver nanoparticle } \\
\text { synthesized from } \\
\text { aqueous extract of } \\
\text { I. aspalathoides }\end{array}$ & $\begin{array}{c}\text { Ascorbic acid } \\
\text { (Standard) }\end{array}$ \\
\hline 1. & 100 & $69.87 \pm 0.8$ & $63.46 \pm 0.40$ & $83.53 \pm 0.80$ \\
\hline 2. & 200 & $71.79 \pm 1.0$ & $66.02 \pm 0.68$ & $87.73 \pm 0.25$ \\
\hline 3. & 300 & $73.71 \pm 0.50$ & $83.33 \pm 0.45$ & $90.66 \pm 0.40$ \\
\hline 4. & 400 & $75.01 \pm 1.22$ & $84.61 \pm 0.11$ & $92.7 \pm 0.3$ \\
\hline 5. & 500 & $78.84 \pm 0.2$ & $85.89 \pm 0.55$ & $97.9 \pm 0.4$ \\
\hline
\end{tabular}

Table 3B. Anti-oxidant activity of Silver Nanoparticles in Nitric acid assay

\begin{tabular}{|c|c|c|c|c|}
\hline \multirow{2}{*}{$\begin{array}{c}\text { S. } \\
\text { No }\end{array}$} & $\begin{array}{c}\text { Concentration } \\
\mu \mathrm{g} / \mathrm{ml}\end{array}$ & $\begin{array}{c}\text { Aqueous extract of } \\
\text { I. aspalathoides }\end{array}$ & $\begin{array}{c}\text { Silver nanoparticle synthesized from aqueous extract of } \\
\text { I. aspalathoides }\end{array}$ & $\begin{array}{c}\text { Ascorbic acid } \\
\text { (Standard) }\end{array}$ \\
\hline 1. & 100 & $16.6 \pm 0.5$ & $26.56 \pm 0.25$ & $43.36 \pm 0.30$ \\
\hline 2. & 200 & $20.4 \pm 0.36$ & $40.3 \pm 0.3$ & $54.13 \pm 0.25$ \\
\hline 3. & 300 & $26.56 \pm 0.35$ & $50.1 \pm 0.26$ & $65.9 \pm 0.4$ \\
\hline 4. & 400 & $30.2 \pm 0.43$ & $64.13 \pm 0.51$ & $72.23 \pm 0.61$ \\
\hline 5. & 500 & $42.6 \pm 0.7$ & $69.36 \pm 0.58$ & $91.86 \pm 0.45$ \\
\hline
\end{tabular}


Table 3C. Anti-oxidant activity of Silver Nano particles for Total antioxidant assay

\begin{tabular}{|c|c|c|c|}
\hline \multirow[b]{2}{*}{ S. No } & \multirow[b]{2}{*}{ Concentration $\mu \mathrm{g} / \mathrm{ml}$} & \multicolumn{2}{|r|}{ Percentage of Scavenging Activity } \\
\hline & & $\begin{array}{l}\text { Aqueous extract of } \\
\text { I. aspalathoides }\end{array}$ & $\begin{array}{c}\text { Silver nanoparticle synthesized from aqueous extract of } \\
\text { I. aspalathoides }\end{array}$ \\
\hline 1. & 100 & $6.16 \pm 0.20$ & $22.06 \pm 0.30$ \\
\hline 2. & 200 & $21.53 \pm 0.61$ & $39.66 \pm 0.65$ \\
\hline 3. & 300 & $27.36 \pm 0.35$ & $53.46 \pm 0.45$ \\
\hline 4. & 400 & $38.2 \pm 0.26$ & $68.23 \pm 0.32$ \\
\hline 5. & 500 & $46.36 \pm 0.47$ & $79.23 \pm 0.20$ \\
\hline
\end{tabular}

\section{Antimicrobial activity against selected pathogens}

The extract of Indigofera aspalathoides and the silver nanoparticles were studied for their antimicrobial activity against five bacteria (Figure 4A) and five fungi (Figure 4B). Standard antibiotic disc of streptomycin and ketoconazole were used as control. The results are tabulated in Table 4A for bacteria and Table 4B for fungi. Upon comparing the zone of inhibition formed due to both crude plant extract and the bio synthesized nanoparticles, silver nanoparticles exhibited greater antibacterial activity with higher zone of inhibition towards gram negative bacterial species namely Klebsiella pneumoniae and Escherichia coli with $13.06 \mathrm{~mm}$ and $9.56 \mathrm{~mm}$. Similarly, the silver nanoparticles when studied for their antifungal activity showed notable activity with more prone activity towards Aspergillus fumigatus and Aspergillus flavus with $6.76 \mathrm{~mm}$ and $2.1 \mathrm{~mm}$.

A

I
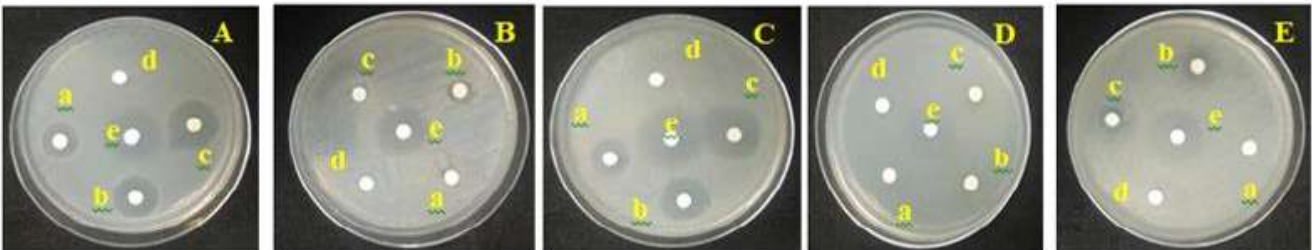

II
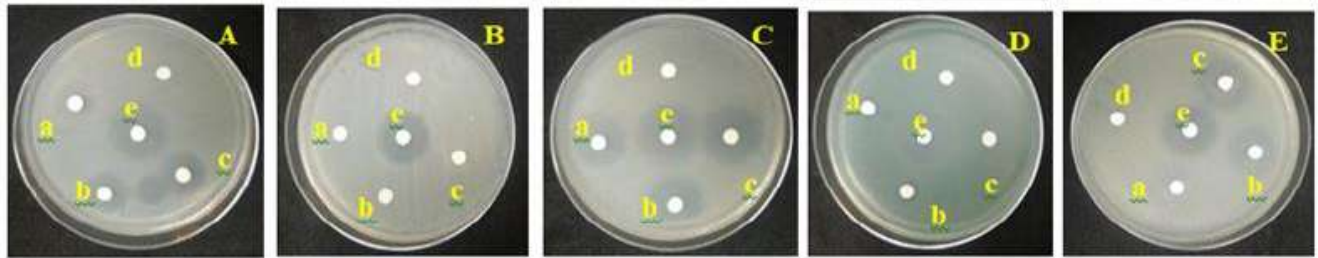

B

I
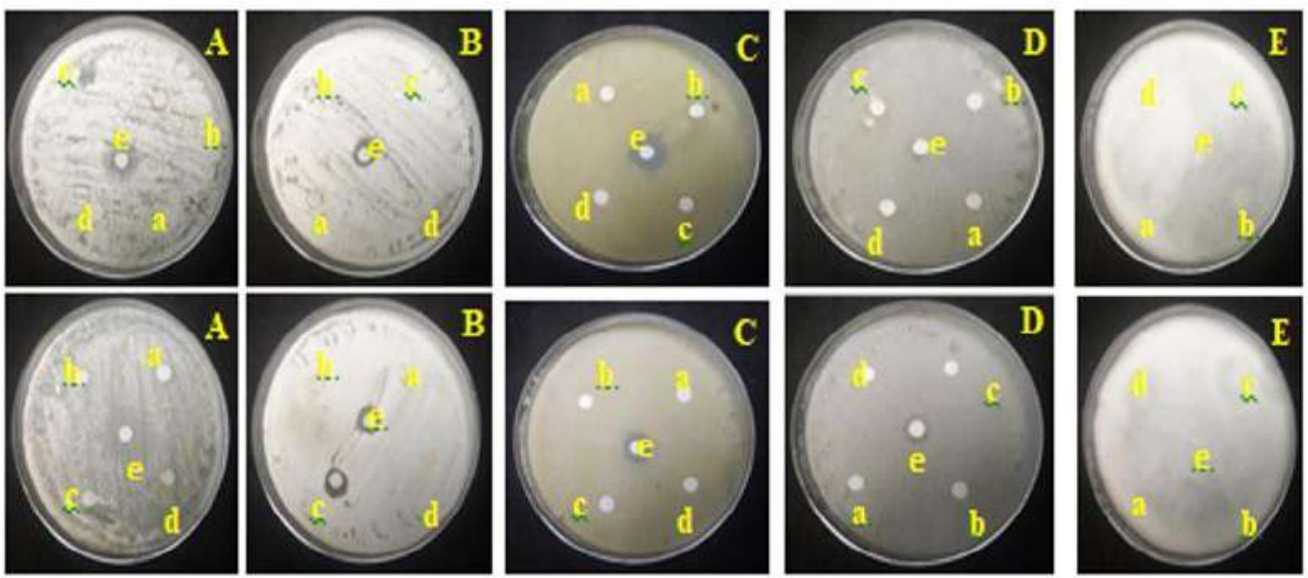

Figure 4. Antimicrobial activity. 4A: I - I. aspalathoides aqueous extract, II- Silver nanoparticle synthesis from I. aspalathoides aqueous extract, A- Bacillus subtilis, B- E. coli, C- Klebsiella pneumoniae, D- Pseudomonas aeruginosa, E- Staphylococcus aureus, a- $250 \mu \mathrm{g}$, b- $500 \mu \mathrm{g}$, c- $1000 \mu \mathrm{g}$, d- DMSO, e- streptomycin $(10 \mu \mathrm{g})$. 4B: I - I. aspalathoides aqueous leaves extract, II- Silver nanoparticle synthesis from I. aspalathoides aqueous leaves extract, A-Aspergillus flavus, B- Aspergillus fumigatus, C- Aspergillus niger, D- Mucor sp., E- Trichoderma sp., a- $250 \mu \mathrm{g}, \mathrm{b}-500 \mu \mathrm{g}, \mathrm{c}-1000 \mu \mathrm{g}$, d- DMSO, e- Ketoconazole $(10 \mu \mathrm{g})$. 
Table 4A. Evaluation of Antibacterial activity by measuring Zone of Inhibition (in $\mathrm{mm}$ )

\begin{tabular}{|c|c|c|c|c|c|c|}
\hline \multirow{2}{*}{ Test Compound } & \multirow{2}{*}{ Concentration $\mu \mathrm{g} / \mathrm{ml}$} & \multicolumn{5}{|c|}{ Microorganisms - Bacterial Species } \\
\cline { 3 - 7 } & & P. aeruginosa & K. pneumoniae & E. coli & B. subtilis & S. aureus \\
\hline \multirow{3}{*}{\begin{tabular}{c} 
I. aspalathoides aqueous extract \\
\cline { 2 - 7 }
\end{tabular}} & 250 & $1.2 \pm 0.91$ & $4.16 \pm 0.56$ & 0 & $7.26 \pm 0.25$ & $3.3 \pm 0.36$ \\
\cline { 2 - 7 } & 500 & $2.4 \pm 0.45$ & $6 \pm 0.3$ & $2.1 \pm 0.1$ & $8.6 \pm 0.55$ & $4.36 \pm 0.35$ \\
\hline \multirow{2}{*}{$\begin{array}{c}\text { Silver nanoparticle synthesized from } \\
\text { I. aspalathoides aqueous extract }\end{array}$} & 1000 & $2.7 \pm 0.7$ & $10.83 \pm 0.80$ & $4.16 \pm 0.20$ & $11.3 \pm 0.36$ & $4.43 \pm 0.40$ \\
\cline { 2 - 7 } & 250 & $2.7 \pm 0.65$ & $7.33 \pm 0.30$ & $6.76 \pm 0.75$ & 0 & $2.3 \pm 0.1$ \\
\cline { 2 - 7 } & 500 & $3.53 \pm 0.47$ & $10.33 \pm 0.41$ & $6.13 \pm 0.32$ & $1.2 \pm 0.3$ & $4.36 \pm 0.32$ \\
\hline Streptomycin (Standard Drug) & 1000 & $4.83 \pm 0.37$ & $13.06 \pm 0.40$ & $9.56 \pm 0.66$ & $1.7 \pm 0.7$ & $4.96 \pm 0.25$ \\
\hline DMSO (Solvent - Blank) & 10 & $12.16 \pm 0.56$ & $14.06 \pm 0.70$ & $9.3 \pm 0.36$ & $19.26 \pm 0.37$ & $7.96 \pm 0.45$ \\
\hline
\end{tabular}

Table 4B. Evaluation of Antifungal activity by measuring Zone of Inhibition (in $\mathrm{mm}$ )

\begin{tabular}{|c|c|c|c|c|c|c|}
\hline \multirow{2}{*}{ Test Compound } & $\begin{array}{c}\text { Concentration } \\
\mu \mathrm{g} / \mathrm{ml}\end{array}$ & \multicolumn{5}{|c|}{ Microorganisms -Fungal Species } \\
\cline { 3 - 7 } & & A. niger & A. flavus & A. fumigatus & Mucor sp. & Trichoderma sp. \\
\hline \multirow{3}{*}{ I. aspalathoides aqueous extract } & 250 & $1.1 \pm 0.10$ & $0.9 \pm 0.32$ & $0.7 \pm 0.11$ & $0.9 \pm 0.45$ & $1.3 \pm 0.51$ \\
\cline { 2 - 7 } & 500 & $1.4 \pm 0.21$ & $1.1 \pm 0.14$ & $1.3 \pm 0.48$ & $1.1 \pm 0.74$ & $1.5 \pm 0.23$ \\
\cline { 2 - 7 } & 1000 & $2.1 \pm 0.12$ & $2.4 \pm 0.36$ & $1.9 \pm 0.21$ & $1.7 \pm 0.75$ & $1.2 \pm 0.46$ \\
\hline \multirow{2}{*}{$\begin{array}{c}\text { Silver nanoparticle synthesized from } \\
\text { I. aspalathoides } \text { aqueous extract }\end{array}$} & 250 & $0.9 \pm 0.10$ & $1.3 \pm 0.16$ & $1.9 \pm 0.31$ & $0.6 \pm 0.27$ & $1.3 \pm 0.46$ \\
\cline { 2 - 7 } & 500 & $1.1 \pm 0.29$ & $1.7 \pm 0.13$ & $2.8 \pm 0.75$ & $1.2 \pm 0.65$ & $1.6 \pm 0.47$ \\
\hline Ketoconazole (Standard Drug) & 1000 & $1.5 \pm 0.62$ & $2.1 \pm 0.86$ & $6.76 \pm 0.80$ & $1.7 \pm 0.53$ & $1.8 \pm 0.71$ \\
\hline DMSO (Solvent - Blank) & 10 & $6.33 \pm 0.49$ & $6.03 \pm 0.35$ & $4.46 \pm 0.41$ & $4.43 \pm 0.45$ & - \\
\hline
\end{tabular}

\section{Cytotoxicity effect}

The extract of Indigofera aspalathoides were studied for their cytotoxic activity against MCF7 cells and is showed in Figure 5A. Similarly, the silver nanoparticles which was synthesized from the extract of Indigofera aspalathoides were also studied for their cytotoxic activity against MCF7 cells and is showed in Figure 5B. Viability percentage of MCF 7 under various concentrations the aqueous extract of Indigofera aspalathoides and the synthesized silver nanoparticles from the extract is listed in the Table 5. After the addition of silver nanoparticle in different concentrations, the inhibition of MCF7 proliferation took place, as shown in the graphical representation. At concentrations higher than $8000 \mathrm{ng} / \mathrm{ml}$, they became necrotic and detached from the culture dishes (McNeil [36]). Morphological changes were observed in the cells for silver nanoparticles at concentrations higher than $100 \mathrm{ng} / \mathrm{ml}$. Thus, the extracted silver nanoparticles showed promising results in anticancer activity or cytotoxic effect against breast cancer (MCF 7) cell lines with lowest cell viability of cancer cells with an IC 50 value of $5.9 \mu \mathrm{g} / \mathrm{ml}$.

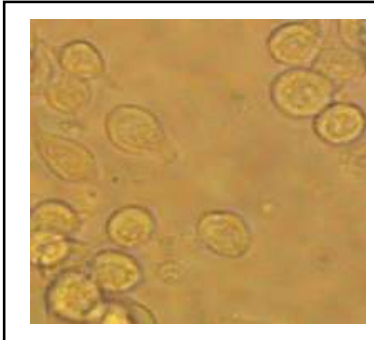

A

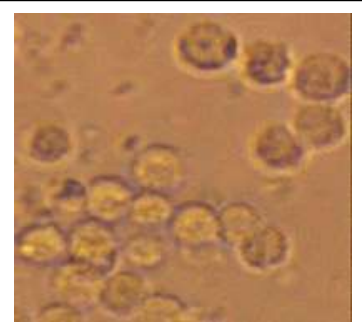

B

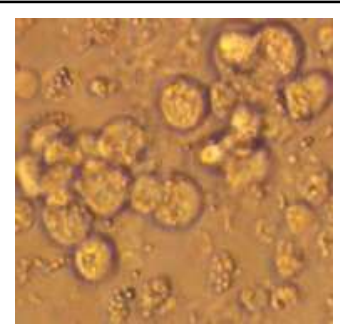

C

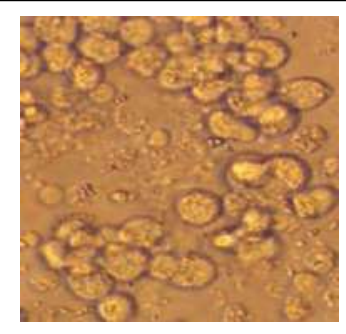

D

Figure 5A. I. aspalathoides aqueous extract A- $12 \mu \mathrm{g} / \mathrm{ml}, \mathrm{B}-25 \mu \mathrm{g} / \mathrm{ml}$, C- $50 \mu \mathrm{g} / \mathrm{ml}$, D- $100 \mu \mathrm{g} / \mathrm{ml}$.

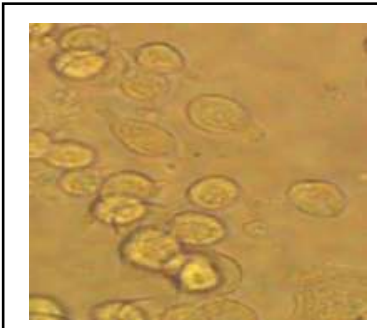

A

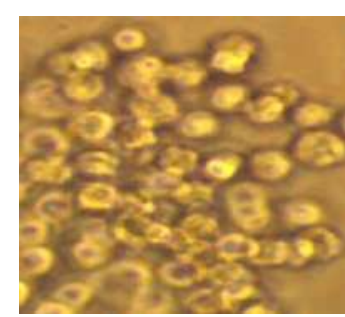

B

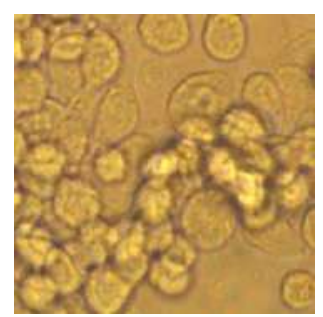

C

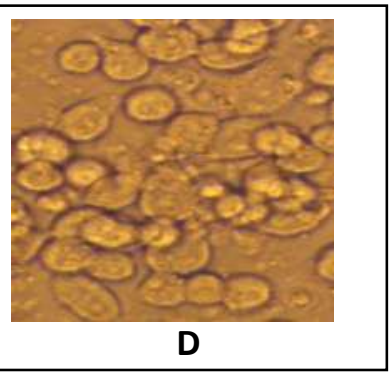

Figure 5B. Silver nanoparticle synthesis from $I$. aspalathoides aqueous extract A- $12 \mu \mathrm{g} / \mathrm{ml}$, B- $25 \mu \mathrm{g} / \mathrm{ml}$, C- $50 \mu \mathrm{g} / \mathrm{ml}, \mathrm{D}-100 \mu \mathrm{g} / \mathrm{ml}$. 
Table 5. Percentage Viability of MCF7 cells treated with I. aspalathoides aqueous extract and Silver nanoparticles

\begin{tabular}{|c|c|c|c|}
\hline \multirow{2}{*}{ S. No } & Concentration & \multicolumn{2}{|c|}{ \% cell Viability } \\
\cline { 3 - 4 } & $\mu \mathrm{g} / \mathrm{ml}$ & I. aspalathoides aqueous extract & Silver nanoparticles synthesized from I. aspalathoides aqueous extract \\
\hline 1 & 100 & $23.46 \pm 0.50$ & $7.76 \pm 0.65$ \\
\hline 2 & 50 & $39 \pm 2.00$ & $12.76 \pm 0.40$ \\
\hline 3 & 25 & $54.33 \pm 2.51$ & $24.3 \pm 1.01$ \\
\hline 4 & 12 & $76.33 \pm 3.05$ & $39.73 \pm 1.01$ \\
\hline
\end{tabular}

\section{Conclusion}

Indigofera aspalathoides leaf extracts are used to synthesize ecofriendly silver nanoparticles. The optimal parameters for efficient silver nanoparticle synthesis: temperature $-50^{\circ} \mathrm{C}, \mathrm{pH}-5$, ratio of the substrates $-1: 2$, and concentration of silver nitrate $-5 \mathrm{mM}$. Characterization and confirmation of synthesized silver nanoparticles were done using different spectral analysis such as FTIR, UV-VIS, AFM, XRD, GCMS and SEM-EDAX. Further its bio activities were studied using different biological assays. The bio synthesized silver nanoparticles retain notable scavenging activity when studied for its antioxidant activity with inhibition percentage of $85 \%$ for DPPH assay, $69 \%$ for Nitric oxide assay and finally $74 \%$ for Total antioxidant assay. Silver nanoparticles also showed a promising antimicrobial activity against different pathogenic microbes by posing higher zone of inhibition in the order Klebsiella pneumoniae (13 mm), Escherichia coli $(9 \mathrm{~mm})$, Aspergillus fumigatus (6 mm), and Aspergillus flavus (2 mm). They also possess cytotoxic effect against breast cancer (MCF7) cells with an IC 50 value of $5.9 \mu \mathrm{g} / \mathrm{ml}$. In the near future, the study will be further evaluated and extended for scale up synthesis of affordable and ecofriendly Ag nanoparticles with antioxidant, antimicrobial and especially anticancer applications for novel product development processes.

\section{Conflict of Interest}

The authors have no conflict of interest to declare.

\section{Acknowledgements/}

\section{References}

1. M. GILAKI. Biosythesis of silver nanoparticles using Plant extracts. Journal of Biological Sciences, 10, pp. 465-467 (2010).

2. D.S. GOODSELL. Bionanotechnology: lessons from nature. John Wiley \& Sons (2004).

3. R.R. PUTHETI, R.N. OKIGBO, M. SAI ADVANAPU, S. CHAVANPATIL. Nanotechnology importance in the pharmaceutical industry, African Journal of Pure and Applied Chemistry, 2, pp. 27-31 (2008).

4. A.Z. WANG, F. GU, L. ZHANG, J.M. CHAN, A. RADOVIC-MORENO, M.R. SHAIKH, O.C. FAROKHZAD. Biofunctionalized targeted nanoparticles for therapeutic applications, Expert Opinion on Biological Therapy, 8(8), pp. 1063-70 (2008).
5. A.M.D. FAROOQUI, P.S. CHAUHAN, P.K. MOORTHY, J. SHAIK. Extraction of silver nanoparticles from the left extracts of clerodendrumincerme, Digest Journal of Nanomaterials and Biostructures, 5, pp. 43-49 (2010).

6. V. KUMAR, S.K. YADAV. Plant-mediated synthesis of silver and gold nanoparticles and their applications, Journal of chemical Technology and Biotechnology, 84, pp. 157-157 (2009).

7. K.S. MUKUNTHAN, S. BALAJI. Cashew apple juice (Anacardium occidentale L.) speeds up the synthesis of silver nanoparticles. International Journal of Green Nanotechnology, 4(2), pp. $71-79$ (2012).

8. K.N. THAKKAR, S.S. MHATRE, R.Y. PARIKH. Biological synthesis of metallic nanoparticles. Nanomedicine: nanotechnology, biology and medicine, 6(2), pp. 257-262 (2010).

9. J.S. KIM, E. KUK, K.N. YU, J.H. KIM, S.J. PARK, H.J. LEE, S.H. KIM, Y.K. PARK, Y.H. PARK, C.Y. HWANG, Y.K. KIM. Antimicrobial effects of silver nanoparticles. Nanomedicine: Nanotechnology, Biology and Medicine, 3(1), pp. 95-101 (2007).

10. J.Y. SONG, H.K. JANG, B.S. KIM. Biological synthesis of gold nanoparticles using Magnolia kobus and Diopyros kaki leaf extracts. Process Biochemistry, 44(10), pp. 1133-1138 (2009).

11. D. JAIN, H.K. DAIMA, S. KACHHWAHA, S.L. KOTHARI. Synthesis of plant-mediated silver nanoparticles using papaya fruit extract and evaluation of their anti microbial activities. Digest journal of nanomaterials and biostructures, 4(3), pp. 557-563 (2009).

12. C. MARAMBIO-JONES, E.M. HOEK. A review of the antibacterial effects of silver nanomaterials and potential implications for human health and the environment. Journal of Nanoparticle Research, 12(5), pp. 1531-1551 (2010).

13. P. RAMANA. Quality control and standardization of herbal drugs-A tool to promote herbal products". In National Conference on 'Recent Trends in Medicinal Plant Research', Centre for Advance Studies in Botany, University of Madras, Chennai, India (2007).

14. N. TAMILSELVI, R. DHAMOTHARAN, P. KRISHNAMOORTHY, J. SHIVAKUMAR. Anatomical studies of Indigofera aspalathoides Vahl (Fabaceae). Journal of Chemical and Pharmaceutical Research, 3(2), pp. 738-746 (2011).

15. S. SILVER, L.T. PHUNG, G. SILVER. Silver as biocides in burn and wound dressings and bacterial 
resistance to silver compounds. Journal of Industrial Microbiology and Biotechnology, 33(7), pp. 627-634 (2006).

16. A. KHANDELWAL SINGH, D. JAIN, M.K. UPADHYAY N., H.N. VERMA. Green synthesis of silver nanoparticles using Argemone mexicana leaf extract and evaluation of their antimicrobial activities. Digest Journal of Nanomaterials and Biostructures, 5(2), pp. 483-489 (2010).

17. S. GARIMA, B. RIJU, K KUNAL, R.S. ASHISH, P.S. RAJENDRA. Biosynthesis of silver nanoparticles using Ocimum sanctum (Tulsi) leaf extract and screening its antimicrobial activity. Journal of Nanoparticle Research, 13(7), pp. 2981-2988 (2010).

18. S.S. SHANKAR, A. RAI, A. AHMAD, M. SASTRY. Rapid synthesis of $\mathrm{Au}, \mathrm{Ag}$, and bimetallic Au core Ag shell nanoparticles using Neem (Azadirachta indica) leaf broth. Journal of colloid and interface science, 275(2), pp. 496-502 (2004).

19. R. VEERASAMY, T.Z. XIN, S. GUNASAGARAN, T.F.W. XIANG, E.F.C. YANG, N. JEYAKUMAR, S.A. DHANARAJ. Biosynthesis of silver nanoparticles using mangosteen leaf extract and evaluation of their antimicrobial activities. Journal of saudi chemical society, 15(2), pp. 113-120 (2011).

20. P. PREMA. Chemical mediated synthesis of silver nanoparticles and its potential antibacterial application. Progress in Molecular and Environmental Bioengineering-From Analysis and Modeling to Technology Applications, 6, pp. 151-166 (2011).

21. M.L. RAO, N. SAVITHRAMMA. Biological synthesis of silver nanoparticles using Svensonia Hyderabadensis leaf extract and evaluation of their antimicrobial efficacy. Journal of Pharmaceutical Sciences and Research, 3(3), p. 1117 (2011).

22. K.D. ARUNACHALAM, J.K. KURUVA, S. HARI, S.K. ANNAMALAI, K.V. BASKARAN. HPTLC Finger print analysis and Phytochemical Investigation of Morinda tinctoria Roxb. Leaf extracts by HPLC and GS MS. International Journal of Pharmaceutical Sciences, 7(2), pp. 360-366 (2015).

23. M. OVAIS, I. AHMAD, A.T. KHALIL, S. MUKHERJEE, R. JAVED, M. AYAZ, A. RAZA, Z.K. SHINWARI. Wound healing applications of biogenic colloidal silver and gold nanoparticles: recent trends and future prospects. Applied microbiology and biotechnology, 102(10), pp. 4305-4318 (2018).

24. G. RATHEESH, L. TIAN, J.R. VENUGOPAL, H. EZHILARASU, A. SADIQ, T.P. FAN, S. RAMAKRISHNA. Role of medicinal plants in neurodegenerative diseases. Biomanufacturing Reviews, 2(1), p. 2 (2017).

25. J.Y. SONG, B.S. KIM. Rapid biological synthesis of silver nanoparticles using plant leaf extracts.
Bioprocess and biosystems engineering, 32(1), p. 79 (2009).

26. C. KRISHNARAJ, E.G. JAGAN, S. RAJASEKAR, P. SELVAKUMAR, P.T. KALAICHELVAN, N.J.C.S.B.B. MOHAN. Synthesis of silver nanoparticles using Acalypha indica leaf extracts and its antibacterial activity against water borne pathogens. Colloids and Surfaces B: Biointerfaces, 76(1), pp. 50-56 (2010).

27. S.S. SHANKAR, A. AHMAD, M. SASTRY. Geranium leaf assisted biosynthesis of silver nanoparticles. Biotechnology progress, 19(6), pp. 16271631 (2003).

28. V. PARASHAR, R. PARASHAR, B. SHARMA, A.C. PANDEY. Parthenium leaf extract mediated synthesis of silver nanoparticles: a novel approach towards weed utilization. Digest Journal of Nanomaterials \& Biostructures, 4(1) (2009).

29. S.P. CHANDRAN, M. CHAUDHARY, R. PASRICHA, A. AHMAD, M. SASTRY. Synthesis of gold nanotriangles and silver nanoparticles using Aloevera plant extract. Biotechnology progress, 22(2), pp. 577-583 (2006).

30. A.D. DWIVEDI, K. GOPAL. Biosynthesis of silver and gold nanoparticles using Chenopodium album leaf extract. Colloids and Surfaces A: Physicochemical and Engineering Aspects, 369(1-3), pp. 27-33 (2010).

31. R. SATHYAVATHI, M.B. KRISHNA, S.V. RAO, R. SARITHA, D.N. RAO. Biosynthesis of silver nanoparticles using Coriandrum sativum leaf extract and their application in nonlinear optics. Advanced science letters, 3(2), pp. 138-143 (2010).

32. G. SINGHAL, R. BHAVESH, K. KASARIYA, A.R. SHARMA, R.P. SINGH. Biosynthesis of silver nanoparticles using Ocimum sanctum (Tulsi) leaf extract and screening its antimicrobial activity. Journal of Nanoparticle Research, 13(7), 2981-2988 (2011).

33. A. SINGH, D. JAIN, M.K. UPADHYAY, N. KHANDELWAL, H.N. VERMA. Green synthesis of silver nanoparticles using Argemone mexicana leaf extract and evaluation of their antimicrobial activities. Digest Journal of Nanomaterials \& Biostructures, 5(2), pp. 483-489 (2010).

34. B.W. NEUN, M.A. DOBROVOLSKAIA. Qualitative analysis of total complement activation by nanoparticles. In Characterization of Nanoparticles Intended for Drug Delivery, Humana Press, pp. 237-245 (2011).

35. Y. CHOI, N.H. HO, C.H. TUNG. Sensing phosphatase activity by using gold nanoparticles. Angewandte chemie international edition, 46(5), pp. 707-709 (2007).

36. S.E. MCNEIL (Ed), S.E. MCNEIL (Ed). Unique benefits of nanotechnology to drug delivery and diagnostics. In Characterization of nanoparticles intended for drug delivery, Humana press 697, pp. 71-82 (2011). 